\title{
Erratum to "Heavy Metals in Soils around the Cement Factory in Rockfort, Kingston, Jamaica" [International Journal of Geosciences 2 (2011) 48-54]
}

\author{
Arpita Mandal1, Mitko Voutchkov² \\ ${ }^{1}$ Department of Geography and Geology, University of West Indies, Mona, Jamaica \\ ${ }^{2}$ Department of Physics, University of West Indies, Mona, Jamaica \\ Email: arpita mandal2000@yahoo.com, mitko.voutchkov@uwimona.edu.jm
}

Received July 22, 2010; revised July 25, 2010; accepted July 28, 2010

Copyright (C) 2015 by authors and Scientific Research Publishing Inc.

This work is licensed under the Creative Commons Attribution International License (CC BY).

http://creativecommons.org/licenses/by/4.0/

(c) (i) Open Access

The original online version of this article (Mandal, A. and Voutchkov, M. (2011) Heavy Metals in Soils around the Cement Factory in Rockfort, Kingston, Jamaica. International Journal of Geosciences, 2, 48-54. http://dx.doi.org/10.4236/ijg.2011.21005) as mentioned above was published as a two-author paper mistakenly. To reflect the contribution and responsibility of the third and fourth author as well as the affiliations of the authors at the time of the study, we revised authorship, author affiliations and acknowledgements of the article. The authors wish to correct the errors to:

\section{A. Mandal1* , M. Madourie1, R. Maharagh1, M. Voutchkov² \\ ${ }^{1}$ Department of Geography and Geology, University of West Indies, Mona, Jamaica \\ ${ }^{2}$ Department of Physics, University of West Indies, Mona, Jamaica \\ Email: ${ }^{*}$ mandalarpitaster@gmail.com}

\section{Acknowledgements}

The authors greatly acknowledge the services offered by the International Center for Nuclear Science, University of the West Indies, Mona Campus, Department of Chemistry at The University of the West Indies, Mona Campus, Mona GeoInformatics Institute and Mines and Geology Division, Ministry of Energy, Mining \& Telecommunication, in sample analysis and production of the map of the cement factory showing sites of sample collection. Acknowledgments are also due to the New Initiative Programme of The University of the West Indies, Mona Campus, Kingston, Jamaica which helped in securing the "New Initiative Grant” by A. Mandal for conducting the research.

${ }^{*}$ Corresponding author. 